\title{
BLINDSTITCH MACHINES FOR MEN SUIT MANUFACTURING, PART 2
}

\author{
Ineta Nemeša ${ }^{1 *}$
}

Professional paper

UDC: 687.1:646.4

doi: $10.5937 /$ tekstind $2103041 \mathrm{~N}$

1Technical faculty "Mihajlo Pupin", University of Novi Sad, Zrenjanin, Serbia

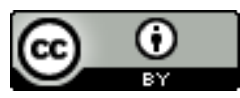

*e-mail: inetavil@gmail.com

Abstract: Different blindstitch machines are used in men suit industrial manufacturing process to replace traditional manual sewing techniques and ensure high work process productivity. The waistband of the trousers is felled with special machines of stitches 103. Beltloop machines process double-folded belt loops for trousers with or without inserted tape. To create 3D shape to lapels and collars of jacket padding machines are used. Spot tacking machines fix together two or more layers of fabric with stitches invisible on the face side of the garment. Machines for felling undercollars create V-shaped zig-zag stitches 314. Two kind of machines are used to fell the lining in the armhole and bottom of the sleeve. Blindstitch machines for certain technological operations are manufactured by companies: Strobel, Maier, Japsew, Global, others.

Keywords: blindstitch machines, men suit manufacturing, machine stitches, felling, padding, spot tacking.

\section{ŠIVAĆE MAŠINE SLEPIH UBODA ZA IZ- RADU MUŠKIH ODELA, DEO 2}

Apstrakt: Različite mašine slepih uboda se koriste za industrijsku izradu muških odela. One zamenjuju tradicionalne manualne tehnike izrade muških odela i poboljšavaju produktivnost rada. Mašine za slepo porubljivabje pojasa prave ubode 103. Mašine za izradu gajka za pojas prave duplo-savijene gajke sa i bez međupodstave. Da bi rever i okovratnik sakoa dobili 3D oblik koriste se mašine za slepo našivenje međupostava. Mašine za izradu slepih ojačanja fiksiraju zajedno dva ili više slojeva materijala tako da mesto ojačanja nije vidljivo na licu odevnog predmeta. Mašina za slepo našivanje donjeg okovratnika pravi cik-cak ubode 314. Dve različite mašine se koriste za fiksiranje podstave u otvoru za rukavi na kraju rukava. Mašine slepih uboda za specijalnu namenu se izrađuju kompanije: Strobel, Maier, Japsew, Global, druge.

Ključne reči: mašine slepih uboda, izrada muških odela, mašinski ubodi, slepo našivanje, slepo učvrćivanje. 


\section{INTRODUCTION}

The most often blindstitch machines are used for hemming operations in production of men and women clothing where invisible hemming is necessary $[1,5]$. However, several other kind of blindstitch machines are developed and used in men suit industrial manufacturing process to replace traditional manual sewing techniques [2] and ensure high work process productivity.

Different specific use blindstitch machines create stitches of classes 100 and 300 [3]. They use to be equipped with un-typical work surfaces, material feeding systems and special additional attachments to perform one certain technological operation $[5,6,7]$.

\section{MACHINES FOR WAISTBAND FELLING}

The waistband of the trousers is felled with special machines of stitches 103. The felling seam use to be placed at the edge of the waistband lining (American/Western style) or on a waistband lining (European style), (see Fig.1). There are machines which can perform both kind (Strobel, Maier) or one kind of felling only (Japsew J-805 for Western trousers waist). To improve fabric feeding, the machines can be equipped with a traditional top feed mechanism and also bottom belt feed. The double feeding system helps to ensure qualitative feeding of heavy, as well as, delicate fabrics (cord, velvet). Sewing speed - up to 3000 stitches per minute. The waistband felling machines are produced by companies: Strobel, Maier, Japsew, Global, others.
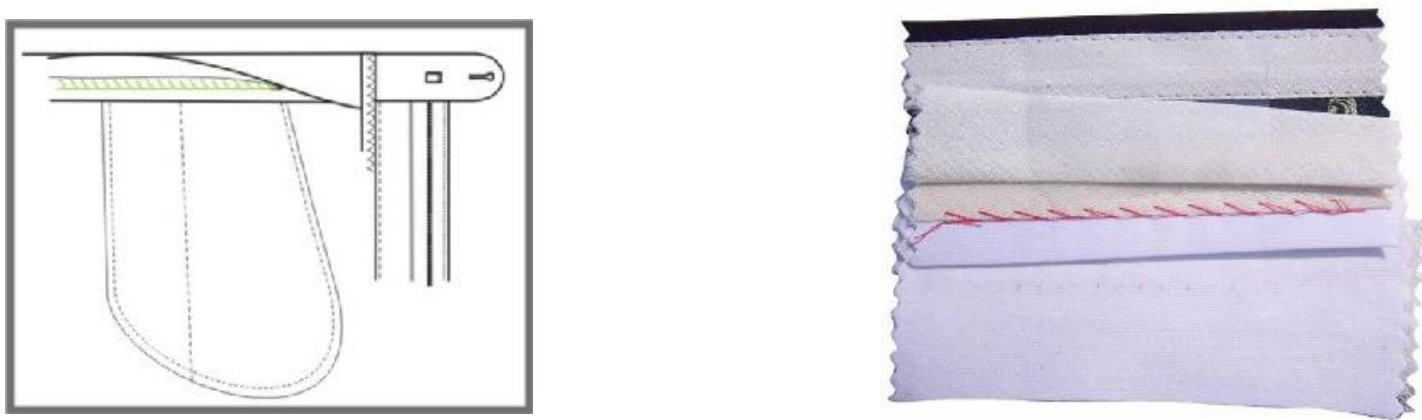

Figure 1. Waistband feeling on a waistband lining

\section{MACHINES FOR BELTLOOP MANUFAC- TURING (BELTLOOP SEWING MACHINES)}

The machines process double-folded belt loops for trousers with or without inserted tape (see Fig. 2). The special folders are used to fold fabric stripes of different widths and fabric thicknesses. Directly before the folder the fabric stripes are automatically cut precisely by two knives (see Fig.3). The machine can be also equipped with a front feed, interlining attachment, an ironing/pressing device (with or without steam), a rolling up device (Maier) and a cutter of ready belt loops (AMF Reece). Sewing speed - up to 2500 stitches per minute.
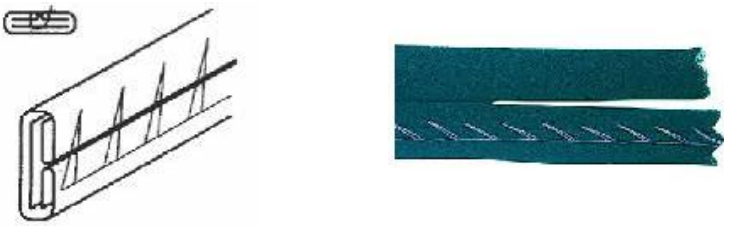

Figure 2. Beltloops of trousers manufactured with blindstitches 103

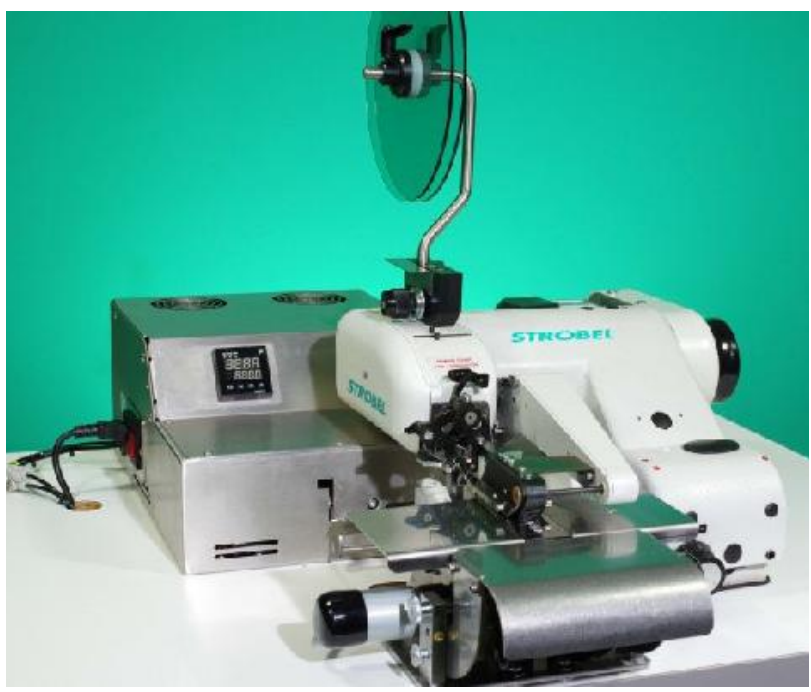

Figure 3. Beltloop machine Strobel VEB100-7

The beltloop machines are produced by companies: Strobel, Maier, Japsew, Global, US blindstitching, others. 


\section{MACHINES FOR ROLL PADDING OF IN- TERLINING (PADDING MACHINES)}

To create 3D shape to lapels and collars of jackets (see Fig.4), the padding machines are equipped with a curved work surface called a roll horn on which the processed part of a jacket can be slightly curved during a padding operation (see Fig.5). If the roll horn is removed and optional fabric support table is fixed in, flat padding can be carried out as well (for padding of chest pieces and interlinings, a facing attaching, blind stitching of a breaktape). Machines can have also a long arm to pad large dimension goods (overcoats, others).
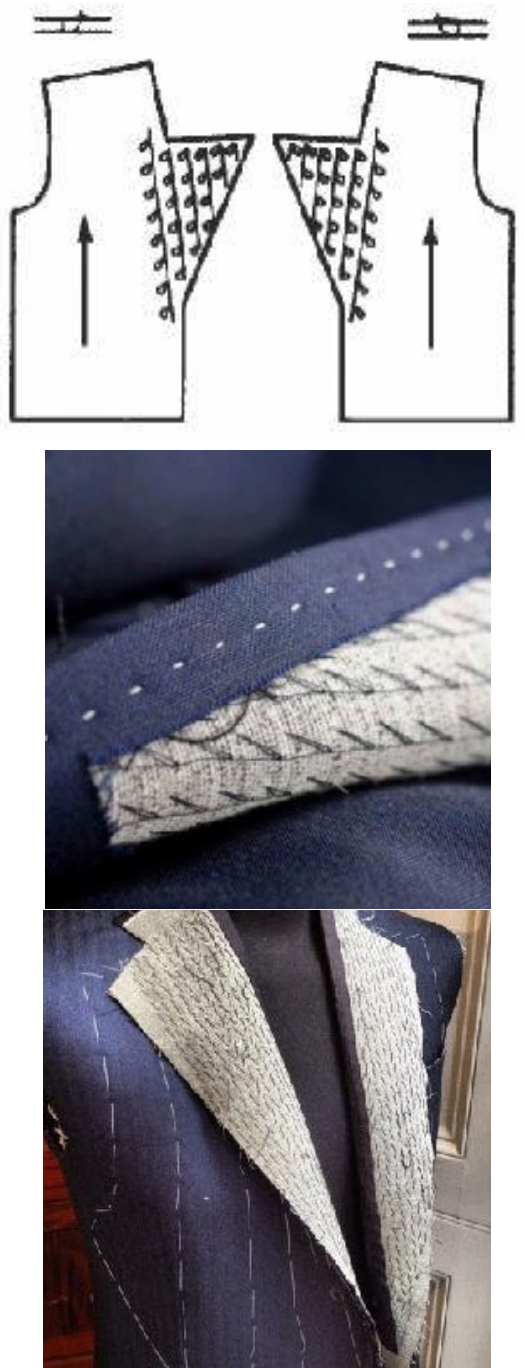

Figure 4. Roll padding of lapels

Automated roll padding on both right and left lapels can be performed by 2-head blindstitch machines: Maier 230RPA, Strobel KA-ED, (see Fig.5). Their sewing parameters are programmed: seam distances, sewing speed, stitch length and the roll effect. Sewing speed - up to 3000 stitches per minute.

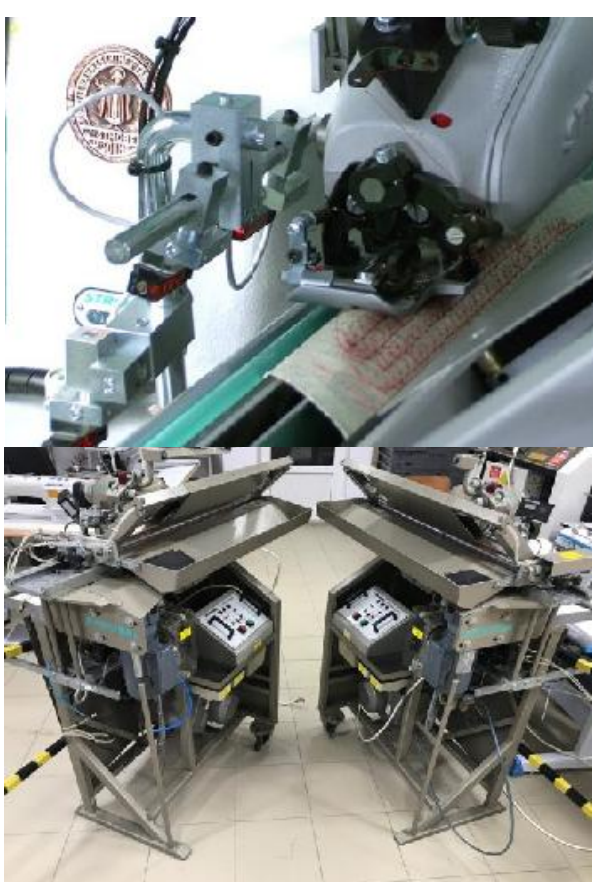

Figure 5. Automated roll padding machine

The padding machines are produced by companies: Strobel, Maier, Japsew, others.

\section{MACHINES FOR SPOT TACKING (BLIND STOP TACKS)}

The machines create determined number of sinlge thread stitches 103 on one spot to fix together two or more lays of fabric with stitches invisible on the face side of the garment. The number of stitches can be pre-selected $(6,8,12$, other) and programmed. Machines have thread trimmer (activated by pedal or automated), can have a pneumatic cutting device, a lifting presser foot and a round work surface (see Fig.6).
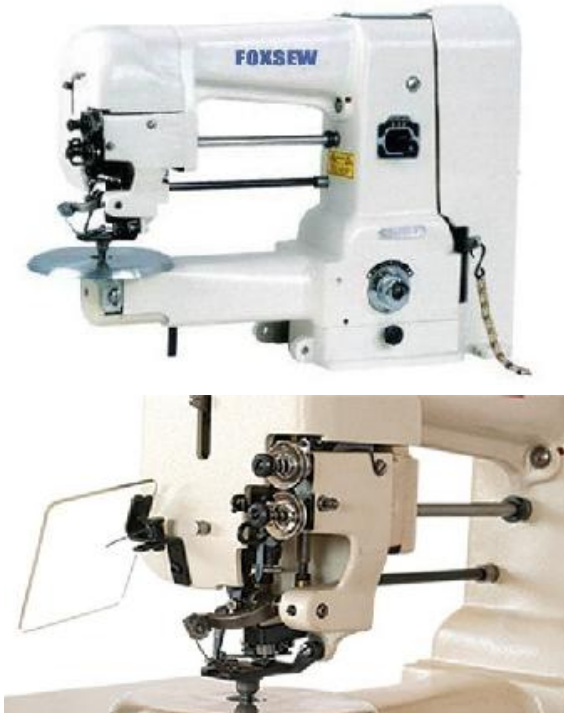

Figure 6. Spot tacking machines 
In men suit manufacturing the machines are used for tacking labels, for securing linings, seam and hem inserts, lapel points, waistband linings, pockets and turned-up bottoms of trousers (see Fig. 7). Sewing speed - up to 1800 stitches per minute.

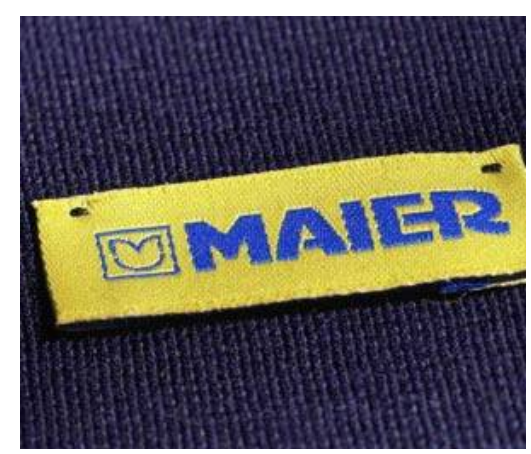

a

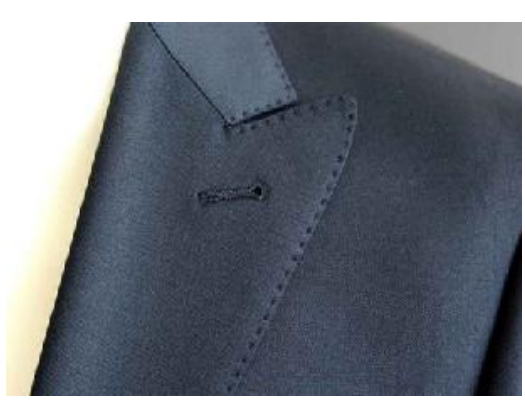

b

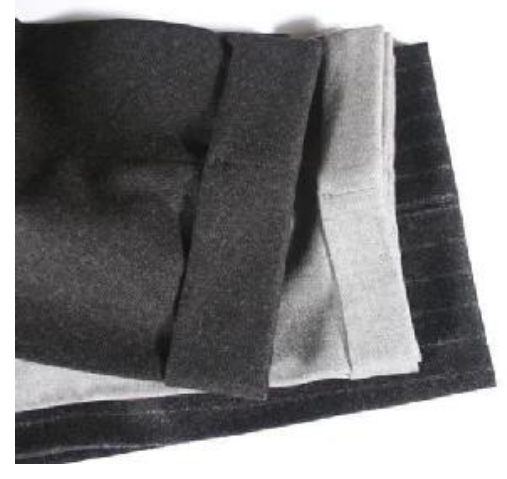

C

Figure 7. Labels (a), lapel points (b) and turned-up bottoms of trousers (c) fixed with spot tacking machine.

The spot tacking machines are produced by companies: Strobel, Maier, Japsew, others.

\section{MACHINES FOR FELLING UNDERCOLLARS (UNDERCOLLAR FELLING MACHINE)}

The machines create V-shaped zig-zag stitches 314 (see Fig. 8,9). The two-step-plunger allows even zig-zag stitch formation for jackets with big difference in fabric thickness at the under collar.
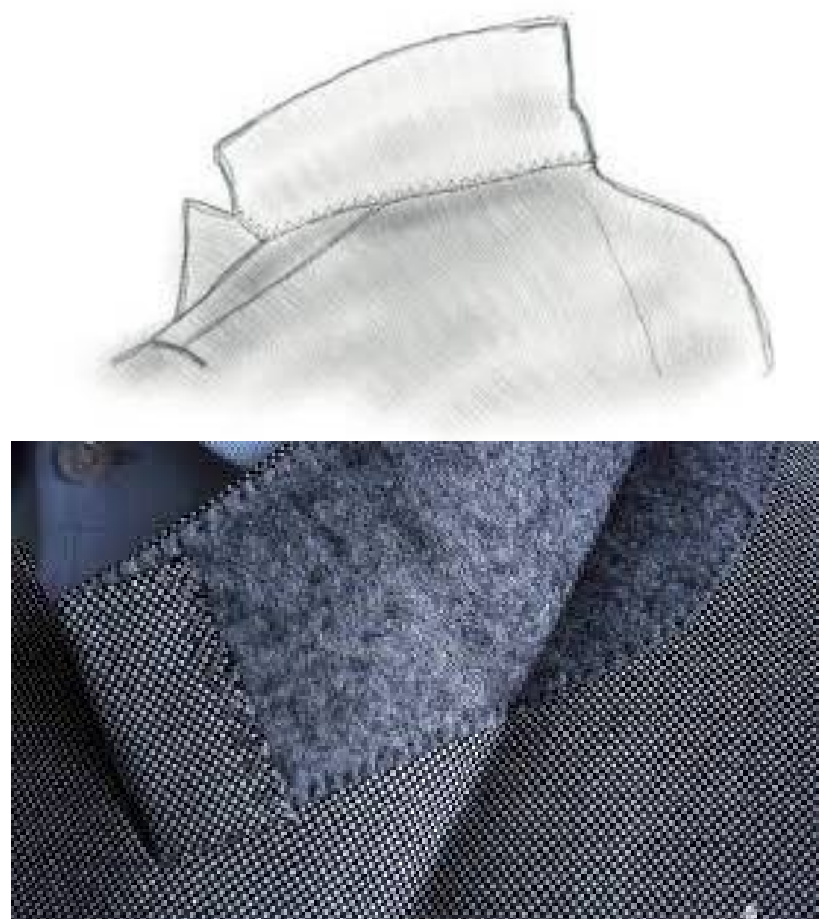

Figure 8. Felling of undercollar of a jacket

Sewing speed - up to 1300 stitches per minute. The machine $218 \mathrm{D}$ is produced by company Strobel.

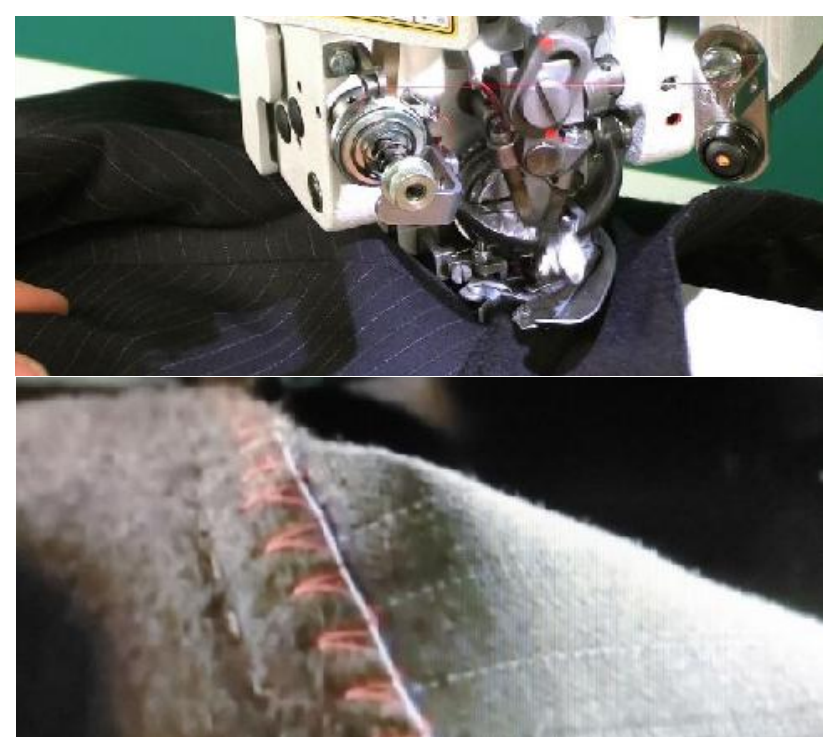

Figure 9. The undercollar felling machine Strobel 218D 


\section{MACHINES FOR FELLING SLEEVE LINING IN THE ARMHOLE}

Tailors baste/sew the seam allowances of the lining to the seam allowances of the sleeve. After it the armhole of the jacket and the lining act as one unit and lining cannot twist, bunched or caught in the jacket. Besides, stitching through multiple layers makes the upper part of the armhole firmer. As a lot of different fabric lays are fixed together (the jacket, a sleeve, many layers of canvas, a felt in the sleeve head), the very loose stitches have to be created which do not compress these layers and with it negatively affect the expression of a shoulder (see Fig.10).

To perform described operation blindstitch machines use lockstitches 317. From the left side of a jacket the upper part of the sleeve lining is attached to the sleeve cap. The machines are equipped with an additional top feed mechanism to improve seam quality stitching on shoulder pads. The machines have cylinder arm only. Sewing speed - up to 1300 stitches per minute. The machine 325-40DTP is produced by company Strobel (see
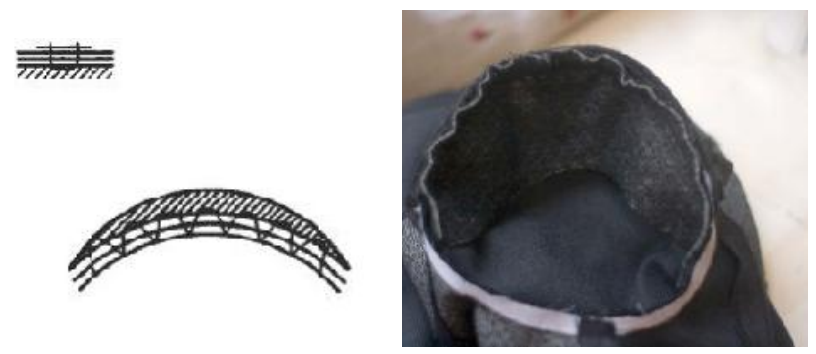

Figure 10. Sleeve cup in the manufacturing process (a) and stitches trough shoulder pad (b).

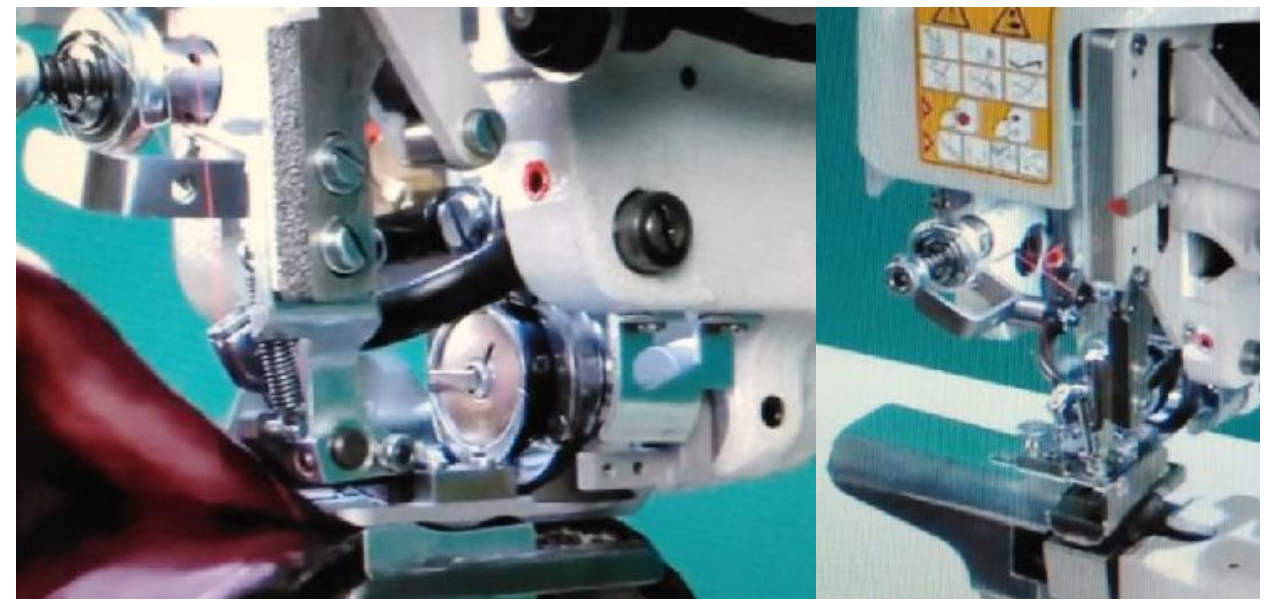

Figure 11. Blindstitch machine Strobel 325-40DTP

\section{MACHINES FOR FELLING SLEEVE LIN-}

\section{ING}

The machine fells lining of sleeves at the cuff of a jacket from the inside with stitches 318 (see Fig.12). The differential upper feed is adjustable during sewing to ensure a needed fullness in the lining. Minimum distance between seam line and button edge is $8 \mathrm{~mm}$.Sewing speed - up to1800 stitches per minute. The machines are produced by company Strobel, Maier.

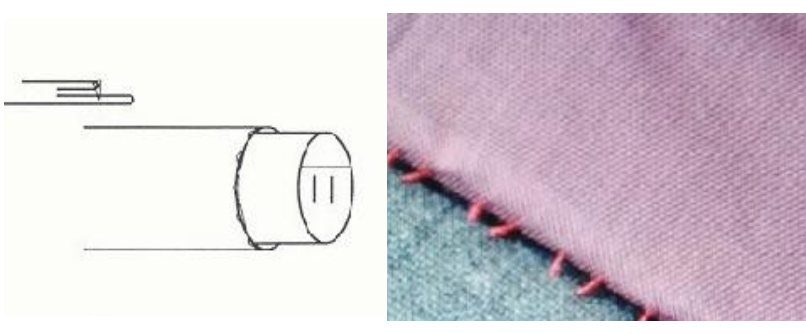

Figure 12. Felling of a sleeve 


\section{CONCLUSION}

There are not many companies which develop specialized sewing machines for men suit manufacturing. The most well known of them, are company Strobel and Maier. They offer the widest range of specialized blindstitch machines. The producers of men suits have to obtain these machines as only by help of them the industrial manufacturing of men suits can ensure traditionally demanded high quality of ready goods and, the same time, effective work process.

\section{REFERENCES}

[1] Nemeša, I. (2021). Blindstitch machines for men suit manufacturing, part 1, Tekstilna Industrija, 69 (2), 34-40.

[2] Cabrera R., Antoine D. (2015). Classic Tailoring Techniques for Menswear. Bloombury.

[3] ISO 4915:1991(en) Textiles-Stitch types-Classification and terminology

[4] Colovic, G. (2015). Sewing, stitches and seams. In: In: Nayak R., Padhye R. ed. Garment Manufacturing Technology, Woodhead Publishing, Elsevier, Cambridge, 247-273.
[5] Blindstitch machines, available on: http://muriscut. com/blindstitch-machines/

[6] Jana, P. (2018). Automation in sewing technology. In: Nayak R., Padhye R.ed. Automation in Garment Manufacturing. Woodhead Publishing, Elsevier, Cambridge, 199-236.

[7] Mcloughlin, J., Mitchell, A. (2013). Mechanisms of sewing machines. In: Jones I., Stylios G.K. Joining Textiles. Woodhead Publishing. Cambridge.123-148.

Primljeno/Received on: 09.07.2021.

Revidirano/ Revised on: 23.07.2021.

Prihvaćeno/Accepted on: 25.07.2021.

(C) 2021 Authors. Published by Union of Textile Engineers and Technicians of Serbia. This article is an open access article distributed under the terms and conditions of the Creative Commons Attribution 4.0 International license (CC BY) (https://creativecommons.org/ licenses/by/4.0/) 